\title{
Effect of Claims Payments on Profitability in The Nigerian Insurance Industry
}

\author{
Taofeek Sola Afolabi \\ Department of Financial Studies \\ Redeemer's University, Ede, Osun state, Nigeria.
}

\begin{abstract}
Profitability determines an insurance company's ability to make claims payments as at when due. The objective of this study is to examine the effect of claims payments on the profitability of insurance companies in Nigeria. Secondary data were generated from the financial statements of the two selected insurance companies, covering the periods 2011 to 2016. Using descriptive statistics and the multiple regression techniques, the data was analyzed with the aid of the Statistical Package for Social Sciences (SPSS version 23). The result reveals that ROA (profitability) has an indirect relationship with LR (loss ratio) and NC (net claims), but a direct relationship with ER (expense ratio). It further reveals that net claims have a significantly positive impact on loss ratio. The study recommends that the Nigerian insurance industry must effectively manage their claims processes, in order to reduce the amount of claims for every earned premium.
\end{abstract}

Keywords: Claims Management, Insurer, Policyholder, Premium.

\section{INTRODUCTION}

Insurance companies sell promises to people, in form of policies. This is a promise to indemnify or bring a policyholder back to his original financial position, prior to the occurrence of a loss. An insurance policy is therefore a promise by the insurer to the policyholder to pay for future claims, while receiving the premium upfront. The settlement of claims is the prime objective of insurance. Policyholders approach an insurer so that in return for the payment of premiums, the company accepts the liability to make a monetary payment to them on the occurrence of a specified event within a specified period of time.

Many scholars have opined that premium income must be sufficiently able to cover claim cost and underwriting expenses (Diacon, 1983; Harrington and Niehaus, 2006; Epetimehin and Ekundayo, 2012). If this basic theory of insurance does not hold, an insurer may delay or find it difficult to pay claims, which can negatively impact the reputation of the company. Nonpayment of claims as at when due, reduces the confidence of the policyholders which in-turn makes it difficult to attract new policyholders, thus producing a negative influence on the profitability of the insurance company.

According to Lalithchanadra and Kumari (2015), claim management includes claims processing and payout, which should be a core element of insurance practices, so as to ensure smooth operations. Yusuf and Dansu (2014) submitted that claims from previous years usually surface in succeeding years, which makes the insurance businesses challenging and the attainment of profitability, very difficult. The Nigerian insurance industry has witnessed rising claims from policyholders. At the end of June 2017, the reported claims in the financial statements of 22 major leading insurance companies showed claims expenses to be over N40 billion as against N34.1 billion in the previous year (Vanguard, 2017). This is a 17.3 percent 
growth, which when compared with the 8.76 percent growth in premium income, recorded in same periods, calls for concern.

This paper intends to show the effect of claims payments on the profitability of selected insurance companies in Nigeria, by examining their claim costs ratio to total cost and the associated expenses, as they influence the profit margin. Results from this study will help to ascertain the extent of the effect of claim management on profitability amongst insurance companies in Nigeria. In addition, there has been misconception about insurance practices in Nigeria, which is giving professionals concern especially the issue of claims settlement (Vanguard, 2017). This paper will thus enable insurance company to plan well for the settlement of claims when they arise.

\section{REVIEW OF RELEVANT LITERATURES}

Irukwu (1989) defines insurance claim as an insurance extract in which the insurer undertakes to indemnify the insured against a loss, which may or may not arise at a future date or to pay a certain amount of money in the happening of a certain event. The loss that is insured against is known as the insured risk. Being legally valid, insurance is enforceable at law. He further stated that the primary duties of the insured under the insurance contract are to pay the agreed premium and to comply with the terms of the policy while the duty of the insurer is to comply with his own terms and promises under the policy and to pay or settle all genuine claims promptly and equitably.

The insurance industry like all other facet of the Nigerian economy is inundated with a number of problems. There is no gainsaying that some, if not all of these problems are capable of being solved by the insurance practitioners with the support of the government and the understanding of the insuring public. About the last thing that comes to the mind of an average Nigerian is the need to effect insurance policies, though business and life itself involve risks (financial or otherwise), many of which could be handled through insurance (Akintayo, 2004).

Irukwu (1989) posits that "a good insurance manager must make efforts towards maintaining an efficient claims department manned by technically competent and reliable personnel". It has also been argued that various organizations since the early 80's have been embracing the management concept represented by the acronym TQM (total quality management) which has helped managers in the resolution of claims and maintenance of a good insurance culture.

However, Mayers and Smith (1988) argued that it is the insurer's responsibility to indemnify a policyholder within the term of the policy". He further opined that when claims are disputed on insubstantial grounds, the insurance industry is brought into disrepute. Hence, insurance companies must ensure payments are promptly made for claims as at when due.

Generally, claim management process consists of four important aspects: settling claims, detecting fraud, lowering costs and avoiding litigation (Lalithchanadra and Kumari, 2015). According to Butler and Francis (2010), claims payment represents the largest single cost to insurers and 80.0 per cent of all premiums are spent on claims payment and associated handling charges. Hence, Redja (2008) opined that claim management includes all managerial decisions and processes concerning the settlement and payment of claims in accordance with the terms of insurance contract.

Greene and Segal (2004), quoted in Kasturi (2006) submitted that the performance of insurance company in financial terms is normally expressed in net premium earned, profitability from underwriting activities, annual turnover, return on investment and return on 
equity. These can be categorized into profit performance measure and investment performance measure. Profit, according to Yusuf and Dansu (2014) is important to investors and management as sources of dividends and growth, while to the policyholder, it provides security against insolvency.

Financial ratios have been agreed and used as measures of profitability (Al-Shami, 2008; Malik, 2011). These ratios include Return on Assets (ROA), Return on Equity (ROE) and Return on Invested Capital (ROIC). ROA is a key indicator since it measures profitability relative to the total assets, which shows how well a company uses its asset to make earnings (Malik, 2011). Profitability in the insurance sector of Nigeria has been seriously affected by rising claim expenses (Vanguard, 2017). The focus of this research is therefore to show the effect of claims payments on the profitability of the Nigerian insurance industry.

\section{METHODOLOGY}

This paper is based on the secondary data from the published annual financial reports of two selected insurance companies in Nigeria, covering the periods 2011 to 2016 (6 years). The insurance companies are American International Insurance Company plc (AIICO) and International Energy Insurance company plc (IEI). The choice of these two, out of the twenty five insurance companies on the floor of the Nigerian Stock Exchange represents 0.08 proportion of the population, and it was carried out by simple random and purposive sampling. According to Amadi (2005), a sample of 0.05 proportion of a population is adequate for making inferences. The data generated from the financial statements of these companies are Return on Assets (ROA), Loss Ratio (LR), Net Claims (NC), Expense Ratio (ER), and the Net Premium (NP), where:

Return on Asset $(\mathrm{ROA})=$ Net Income before taxes/Total Assets,

Loss Ratio (LR) = Total Net Claims/Earned Premium,

Net Claims $(\mathrm{NC})=$ Total claims paid in the year,

Expense Ratio (ER) = Total Underwriting expenses/Earned Premium,

Net Premium (NP) = Total Premium - Premium paid to Re-insurer.

The formulated null hypotheses for this study are;

Hypothesis 1: ROA is not significantly influenced by LR, ER and NC

Hypothesis 2: LR is not significantly influenced by NP and NC.

The linear multiple regression models (adopted from Yusuf and Dansu, 2014) to test these hypotheses are:

$$
\begin{gathered}
\mathrm{ROA}=\alpha_{0}+\alpha_{1}(\mathrm{LR})+\alpha_{2}(\mathrm{ER})+\alpha_{3}(\mathrm{NC})+\varepsilon \\
\mathrm{LR}=\alpha_{0}+\alpha_{1}(\mathrm{NP})+\alpha_{2}(\mathrm{NC})+\varepsilon \ldots \ldots \ldots \ldots \ldots
\end{gathered}
$$

The dependent variables are ROA in model (i.) and LR in model (ii.), while the independent variables are LR, ER and NC in model (i.) and NP and NC in model (ii.).

\section{DATA ANALYSIS AND DISCUSSION}

The data generated were analyzed using descriptive statistics, multiple linear regression and ordinary least square regression techniques, with the aid of the Statistical Package for Social Sciences (SPSS), version 23. 
Table 1: Mean and Standard variation of the explanatory variables for the selected companies

\begin{tabular}{|c|c|c|c|c|}
\hline & AIICO & IEI & AIICO & IEI \\
\hline Variables & Mean & Mean & $\begin{array}{c}\text { Standard } \\
\text { deviation }\end{array}$ & $\begin{array}{c}\text { Standard } \\
\text { deviation }\end{array}$ \\
\hline ROA & 0.52584 & 0.515612 & 0.118653 & 0.131864 \\
\hline LR & 0.63627 & 0.371049 & 0.472019 & 0.119183 \\
\hline NC & $8,475,229,833$ & $1,367,612,000$ & $3,059,197,286$ & $364,489,334$ \\
\hline ER & 1.050955 & 0.640837 & 0.547703 & 0.121901 \\
\hline NP & $16,100,000,000$ & $1,983,506,333$ & $6,601,439,853$ & $1,471,445,766$ \\
\hline
\end{tabular}

Source: Author's computation, 2017.

Table 1 shows the result of the descriptive analysis of the Return on Assets (ROA), Loss Ratio (LR), Net Claims, Expense Ratio (ER), and the Net Premium (NP) of the two insurance companies used for this study for 6 years. A comparative analysis from the table reveals that AIICO did slightly better than IEI in terms of ROA (52.6\% to $51.6 \%$ respectively), but more poorly in term of Loss Ratio (LR) on claim payments from it's total premium (63.6\% to 37.1\% respectively). The mean Net Claim (NC) for AIICO for this period is considerably higher than that from IEI, although the mean premium income (NP) is almost double the NC. IEI could only generate $69 \%$ of its NC as premium income. The standard deviation of the Expense Ratio (ER) for IEI appears to be better than AIICO, suggesting more stable underwriting expenses as compared with the earned premium.

\section{Model 1:}

Table 2: Regression co-efficient, $t$-values and collinearity statistics for the variables

\begin{tabular}{|c|c|c|c|c|c|c|c|c|}
\hline \multirow{2}{*}{\multicolumn{2}{|c|}{ Model }} & \multicolumn{2}{|c|}{$\begin{array}{c}\text { Unstandardized } \\
\text { Coefficients }\end{array}$} & \multirow{2}{*}{$\begin{array}{c}\text { Standardized } \\
\text { Coefficients } \\
\text { Beta } \\
\end{array}$} & \multirow[b]{2}{*}{$\mathrm{T}$} & \multirow[b]{2}{*}{ Sig. } & \multicolumn{2}{|c|}{$\begin{array}{c}\text { Collinearity } \\
\text { Statistics }\end{array}$} \\
\hline & & B & Std. Error & & & & Tolerance & VIF \\
\hline \multirow[t]{4}{*}{1} & (Constant) & .534 & .088 & & 6.091 & .000 & & \\
\hline & Loss Ratio & -.369 & .264 & -1.099 & -1.398 & .200 & .149 & 6.729 \\
\hline & Net Claim & $-1.391 \mathrm{E}-13$ & .000 & -.005 & -.014 & .989 & .712 & 1.404 \\
\hline & $\begin{array}{l}\text { Expense } \\
\text { Ratio }\end{array}$ & .205 & .208 & .745 & .987 & .353 & .161 & 6.206 \\
\hline
\end{tabular}

Source: Author's Field work, 2017

The model obtained from the result of the regression analysis on the variables in the first hypothesis is: $\mathbf{R O A}=0.534-0.369(L R)+0.205(E R)-1.391 E-13(N C)$

The negative co-efficient of the loss ratio (LR) implies that for every unit increase in LR, there is a corresponding decrease of 0.369 in profitability, as measured by ROA, while keeping other variables constant. This shows an indirect relationship between LR and ROA. Thus to maximize profit, an insurer must considerably minimize its claim expenses. This finding is consistent with those of SAS (2012) and Yusuf and Dansu (2014).

Similarly, the positive co-efficient of ER indicates that a unit increase in ER, results into a corresponding increase of 0.205 in ROA. This is a direct correlation between the two variables, thus confirming that ER directly influences the profit margin. It can be inferred that other administrative expenses, also impact on the profitability of insurance companies in Nigeria. 
From the model above, it can further be seen that NC and ROA have an indirect relationship. Keeping all other variable constant, for every one trillion naira increase in NC, there is a corresponding 1.391 decrease in ROA. This could be due to poor claim and risk management, inadequate premium charge and poor loss reserving. These are among the various challenges Nigerian insurers must overcome in order to remain solvent.

The constant value ( $\left.\alpha_{0}=0.534\right)$ implies that, if the independent variables (loss ratio, expense ratio and net claim) are missing, the Return on Asset equals 0.534. This can be translated to mean that an insurance company in Nigeria will still realize profit, even when it does not incur major claim and administrative expenses.

The tolerance values and VIF values in table 2 above respectively identify the problem of multicollinearity in each independent variable. Since the tolerance values of all the independent variable are greater than 0.1 and VIF are less than 10, it shows that the problem of multicollinearity does not exist among all the predictor variables. Hence, all the independent variables were used in the model.

\section{Hypothesis Testing:}

Hypothesis 1: ROA is not significantly influenced by LR, ER and NC

Table 3: Co-efficient of determination $\left(R^{2}\right)$

\begin{tabular}{|l|l|r|r|r|}
\hline $\begin{array}{l}\text { Mode } \\
\mathrm{l}\end{array}$ & $\mathrm{R}$ & $\mathrm{R}$ Square & $\begin{array}{c}\text { Adjusted R } \\
\text { Square }\end{array}$ & $\begin{array}{c}\text { Std. Error of } \\
\text { the Estimate }\end{array}$ \\
\hline 1 & $.515^{\mathrm{a}}$ & .265 & -.010 & .1203169 \\
\hline
\end{tabular}

Source: Author's Field work, 2017

From table 3 above, the co-efficient of determination $\left(\mathrm{R}^{2}\right)$ is 0.265 , suggesting that about $26.5 \%$ of the dependent variable (ROA) is explained by the independent variables (LR, ER and NC). This is the size of the overall effect of all the independent variables.

Table 4: ANOVA

\begin{tabular}{|c|c|c|c|c|c|c|}
\hline \multicolumn{2}{|c|}{ Model } & $\begin{array}{c}\text { Sum of } \\
\text { Squares }\end{array}$ & Df & $\begin{array}{c}\text { Mean } \\
\text { Square }\end{array}$ & $\mathrm{F}$ & Sig. \\
\hline 1 & Regression & .042 & 3 & .014 & .963 & $.456^{b}$ \\
\hline & Residual & .116 & 8 & .014 & & \\
\hline & Total & .158 & 11 & & & \\
\hline
\end{tabular}

Source: Author's Field work, 2017

From table 4, the ANOVA value (F) is 0.963 ( $\mathrm{df}=3$; $\mathrm{p}>0.05$ ), which is not significant at 0.05 level. This shows that there is no significant relationship between ROA, loss ratio, expense ratio and net claims. The null hypothesis 1 is thus accepted, meaning that even though there exists direct or indirect relationship between the dependent and independent variable, the relationship is not significant. The corresponding t-values in table 3 , further support this assertion. 
Model 2:

Table 5: Regression co-efficient, t-values and collinearity statistics for the variables

\begin{tabular}{|c|c|c|c|c|c|c|c|c|}
\hline \multirow{2}{*}{\multicolumn{2}{|c|}{ Model }} & \multicolumn{2}{|c|}{$\begin{array}{c}\text { Unstandardized } \\
\text { Coefficients }\end{array}$} & \multirow{2}{*}{$\begin{array}{c}\begin{array}{c}\text { Standardized } \\
\text { Coefficients }\end{array} \\
\text { Beta }\end{array}$} & \multirow[b]{2}{*}{ 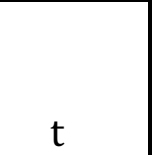 } & \multirow[b]{2}{*}{ Sig. } & \multicolumn{2}{|c|}{$\begin{array}{c}\text { Collinearity } \\
\text { Statistics }\end{array}$} \\
\hline & & $\mathrm{B}$ & Std. Error & & & & Tolerance & VIF \\
\hline \multirow[t]{3}{*}{1} & (Constant) & .455 & .051 & & 8.946 & .000 & & \\
\hline & Net Claim & $1.351 \mathrm{E}-10$ & .000 & 1.613 & 10.911 & .000 & .356 & 2.806 \\
\hline & $\begin{array}{l}\text { Net } \\
\text { Premium }\end{array}$ & $-6.152 \mathrm{E}-11$ & .000 & -1.344 & -9.088 & .000 & .356 & 2.806 \\
\hline
\end{tabular}

Source: Author's Field work, 2017

The model obtained from the result of the regression analysis on the variables in the second hypothesis is: $\mathbf{L R}=\mathbf{0 . 4 5 5}+\mathbf{1 . 3 5 1 E - 1 0 ( N C )}-\mathbf{6 . 1 5 2 E - 1 1 ( N P )}$

The positive co-efficient of NC indicates that for every ten billion naira increase in net claim, the loss ratio increases by 1.35 units. This shows a direct correlation between loss ratio and net claim. Table 5 reveals that this relationship is significant with $\mathrm{t}$-value of $10.911(\mathrm{p}<0.05$; beta $=$ 1.613). The interpretation of this is that $135 \%$ loss is generated from every ten billion naira premium income earned. Since this loss is significant, Nigerian insurance companies must improve on their claim management processes, in order to reduce the amount of claims for every premium collected. Similarly from the model, the negative co-efficient of NP implies that for every hundred billion naira increase in net premium, there is a corresponding decrease of 6.152 units in the loss ratio. The t-value of $-9.088(\mathrm{p}<0.05$ and Beta $=-1.344)$ shows that this relationship is significant. This result is consistent with findings in literatures that when premium growth results in reduction in loss ratio, an insurance company is said to be profitable.

The tolerance values and VIF values in table 5 respectively identify the problem of multicollinearity in each independent variable. Since the tolerance values of all the independent variable are greater than 0.1 and VIF are less than 10, it shows that the problem of multicollinearity does not exist among all the predictor variables. Hence, all the independent variables were used in the model.

\section{Hypothesis Testing:}

Hypothesis 2: LR is not significantly influenced by NP and NC.

Table 6: Co-efficient of determination $\left(\mathrm{R}^{2}\right)$

\begin{tabular}{|l|l|r|r|r|}
\hline $\begin{array}{l}\text { Mode } \\
\mathrm{l}\end{array}$ & $\mathrm{R}$ & R Square & $\begin{array}{c}\text { Adjusted R } \\
\text { Square }\end{array}$ & $\begin{array}{l}\text { Std. Error of } \\
\text { the Estimate }\end{array}$ \\
\hline 1 & $.964^{\mathrm{a}}$ & .930 & .914 & .1042899 \\
\hline
\end{tabular}

Source: Author's Field work, 2017

Table 6 shows that the co-efficient of determination $\left(\mathrm{R}^{2}\right)$ is 0.930 . This suggests that about $93.0 \%$ of the dependent variable (LR) is explained by the independent variables (NC and NP). This is also confirms the size of the overall effect of all the independent variables. 
Table 7: ANOVA

\begin{tabular}{|c|c|c|c|c|c|c|}
\hline & & $\begin{array}{c}\text { Sum of } \\
\text { Squares }\end{array}$ & $\mathrm{df}$ & $\begin{array}{c}\text { Mean } \\
\text { Square }\end{array}$ & $\mathrm{F}$ & Sig. \\
\hline \multirow[t]{3}{*}{1} & Regression & 1.298 & 2 & \multirow{3}{*}{$\begin{array}{l}.649 \\
.011\end{array}$} & \multirow[t]{3}{*}{59.678} & \multirow[t]{3}{*}{$.000^{\mathrm{b}}$} \\
\hline & Residual & .098 & 9 & & & \\
\hline & Total & 1.396 & 11 & & & \\
\hline
\end{tabular}

Source: Author's Field work, 2017

From table 7, the ANOVA value $(\mathrm{F})$ is $59.678(\mathrm{df}=2 ; \mathrm{p}<0.05)$, which is significant at 0.05 level, implies linearity between loss ratio and the predictors. This shows that there exists a significant relationship between dependent variable (loss ratio) and the independent variables (net claims and net premiums). The null hypothesis 2 is thus rejected in favour of the alternative. The model obtained can thus be used for predicting future activities in the Nigerian insurance industry.

\section{CONCLUSION AND RECOMMENDATION}

Profitability in the insurance industry is affected by many factors, including rising claims payments. Profitability determines an insurance company's ability to make claims payments as at when due. The purpose of this study is to examine the effect of claims payments on the profitability of insurance companies in Nigeria. The findings in this study have revealed that ROA, which is a measure of profitability, has an indirect relationship with LR (loss ratio) and $\mathrm{NC}$ (net claims), but a direct relationship with ER (expense ratio). It has further been revealed that net claims positively correlate with loss ratio.

The study recommends that claims managers in the Nigerian insurance industry must effectively manage their claims processes, in order to reduce the amount of claims for every earned premium. In addition, a careful attention must also be given to other administrative cost, such as the underwriting cost, which is capable of reducing the company's profit margin. Future studies can consider the effect of the explanatory variables on other measures of profitability.

\section{References}

Akintayo, L.A. (2004). Introduction to General Insurance Underwriting. Lagos: CSS Bookshops Limited, Vol 2.

Al-Shami, H. (2008) Determinants of Insurance Companies Profitability in UAE. Unpublished Master's Thesis, University of Utara, Malaysia.

Amadi, V.L. (2005) An investigation into the role of private sector in Nigerian higher education: A case study of the University of Abuja. International Journal of Research in Education, 2(1\&2), 113-122.

Butler, S. and Francis, P. (2010) Cutting the cost of Insurance Claims: taking Control of the process. Booz and Company media Uploads. Retrieved from http://www.booz.com

Diacon, S.R. (1983). Principles of Economics. Study Course for CIIN Subject $103 \mathrm{~s}$

Epetimehin, F.M. and Ekundayo, O.A. (2012). The Impact of Risk Pricing on Profit Maximization of Insurance Companies. International Journal of Academic Research in Economics and Management Sciences, 1 (14), 21 - 35

Greene, W.H., and Segal, D. (2004). Profitability and Efficiency in the U.S Life Insurance Industry, Journal of Productivity Analysis. Kluwer Academic Publisher, Netherlands.

Harrington, S.E., and Niehaus, G.R. (2006) Risk Management and Insurace. U.S.A., New York: Mc Graw-Hill Irukwu, J.0. (1989). Insurance Markets in the Third World; Will they Play a Significant Role in the International Insurance Scheme? Insurance Torch Journal, ASINS, ESUT, 1 (2), 13-34

Kasturi, R. (2006). “Performance Management in Insurance Corporation." Journal of Business Administration online 5 (1) 
Lalithchanadra, B.N., and Kumari, T.L. (2015) A Critical Analysis of Individual Death Claims and Benefit Amount Paid in Indian Insurance Industry. Journal of Business and Management Volume 17, Issue 6, PP 22-26

Malik, H. (2011) Determinants of Insurance Companies Profitability: An Analysis of Insurance Sector of Pakistan. Academic Research International, 1 (3).

Mayer, D. and Smith, C. W. (1988). Ownership Structures Across Lines of Propery-Casualty Insurance. Journal of Law and Economics, 13, 351 -378

Redja, G.E. (2008) Principles of Risk Management and Insurance, 10 th Ed. Pearson Education, New York.

Vanguard (2017). Insurance firms pressured by N40bn rising claims, www.vanguardngr.com/2017/09/11insurance-firms-pressured-n40bn-rising-claims/, accessed on December 5, 2017.

Yusuf, T.O., and Dansu F.S. (2014) Effect of Claim Cost on Insurers' Profitability in Nigeria. International Journal of Business and Commerce Vol. 3, No. 10, (01-20) 